\title{
IPTEK BAGI MASYARAKAT PADA KELOMPOK TANI TERNAK DI SUNGAI PERMAI, LAMBUNG BUKIK
}

\author{
Evitayani, Yetti Marlida, Ahadiyah Yuniza, James Hellyward, Suyitman dan Harnentis \\ Fakultas Peternakan Universitas Andalas \\ Email : evitayani.unand@gmail.com
}

Received : 18 Juli 2018. Accepted : 30 Agustus 2018. Published Online 17 September 2018

\begin{abstract}
ABSTRAK
Propinsi Sumatera Barat memiliki pertanian relatif luas dengan bahan pakan seperti jerami padi, Rumput Gajah dan kelompok legume yang dapat dimanfaatkan untuk kebutuhan ternak sapi potong. Luas keseluruhan Kota Padang adalah 694,96 km², dan lebih dari $60 \%$ dari luas tersebut, sekitar \pm 434,63 km² merupakan daerah perbukitan yang ditutupi hutan lindung, sementara selebihnya merupakan daerah efektif perkotaan. Sedangkan keadaan topografi kota ini bervariasi, 49,48\% luas wilayah daratan Kota Padang berada pada wilayah kemiringan lebih dari $40 \%$ dan $23,57 \%$ berada pada wilayah kemiringan landai. Wilayah timur ini terdiri dari beberapa kecamatan yaitu mulai utara ke selatan berturut- turut dari Kecamatan Koto tangah, Pauh, Kuranji, dan Lubuk kilangan. Daerah Pauh seperti desa Lambung Bukik yang termasuk ke dalam program forum Pertides (perguruan tinggi untuk desa) yang bekerjasama yang diawali MOU Rektor tahun 2017 dengan Kemendes PDTT) untuk mempersiapkan dan melaksanakan program membantu desa membangun. Sebagian pendapatan mereka diperoleh dari beternak dan bercocok tanam. Secara umum, baik usaha pertanian maupun peternakan masih dilaksanakan secara tradisional, sehingga tidak mengherankan apabila hasil yang diperoleh pun relatif rendah. Ternak sapi hanya dikandangkan atau ditambatkan pada malam hari, sedangkan siang harinya dilepas untuk mencari makanan dipadang rumput atau dilahan tidur sekitar desa. Baru sedikit upaya untuk memelihara ternak secara intensif dengan mengandangkan dan memberikan makanan secara cukup dan teratur. Rendahnya produksi ternak selain disebabkan oleh kurangnya pengetahuan peternak dalam cara pemeliharaan ternak yang benar, juga karena kurangnya pakan baik hijauan maupun mahalnya harga konsentrat. Dengan meningkatnya populasi ternak tentu membutuhkan hijauan yang lebih banyak dan mencukupi sepanjang tahun. Namun, penyediaan hijauan tersebut mengalami hambatan yang cukup serius. Salah satunya, adanya musim kemarau yang menyebabkan menurunnya produksi hijauan. Oleh karena itu usaha pengembangan ternak sapi potong akan lebih menguntungkan apabila dapat mencari alternatif pengganti hijauan konvensional dengan penggunaan silo sebagai tempat fermentasi pakan. Pemanfaatan hasil ikutan pertanian (seperti jerami padi) dan tanaman pangan lainnya sebagai pakan ternak diharapkan dapat menjawab permasalahan di atas. Hal ini dimungkinkan karena pemeliharaan ternak sapi pada umumnya terintegrasi dengan usaha tani lainnya khususnya tanaman pangan (sawah) sehingga hasil ikutan pertanian akan tersedia sepanjang tahun. Oleh sebab itu, perlulah semacam sentuhan teknologi pakan dengan pemanfaatan agroindustri by product seperti jerami yang terbukti available setiap saat. Pelaksanaan pengaplikasian teknologi amoniasi jerami padi dilapangan dengan pemberian langsung amoniasi yang sudah dismpan dan diber kotoran ayam. Partisipasi dan motivasi kelompok petani peternak dalam mengikuti serangkaian kegiatan sangat tinggi. Karena selama ini belum pernah dilakukan pembinaan yang berkaitan dengan aspek teknis serta manajemen dalam pemeliharaan sapi potong. Peternak sudah tahu bagaimana manajemen dalam penggemukan sapi potong seperti pemberian konsentrat seperti bungkil kelapa, bungkil kedele, tepung ikan, ampas tahu dan dedak serta pemberian mineral premix.
\end{abstract}

Kata Kunci : amoniasi jerami, konsentrat, pakan lokal, rumput gajah

\section{Technology for Communities on Livestock Groups in Sungai Permai, Lambung Bukik}

\begin{abstract}
West Sumatra Province has relatively extensive agriculture with feed ingredients such as rice straw, Rumput Gajah and legume groups that can be used for beef cattle needs. The total area of Padang City is
\end{abstract}


$694.96 \mathrm{~km}^{2}$, and more than $60 \%$ of this area, about $\pm 434.63 \mathrm{~km}^{2}$ is a hilly area covered by protected forests, while the rest is an effective urban area. While the topography of the city varies, $49.48 \%$ of the land area of Padang City is in a slope of more than $40 \%$ and $23.57 \%$ is in the slope of the slope. The eastern region consists of several sub-districts, starting from north to south, respectively from Koto tangah, Pauh, Kuranji, and Lubuk sub-districts. The Pauh region, such as the village of Lambung Bukik, belongs to the Pertides forum program (universities for villages) which collaborates with the 2019 Chancellor's MOU with the Ministry of Education PDTT) to prepare and implement programs to help build villages. Some of their income is obtained from raising livestock and farming. In general, both agricultural and livestock businesses are still carried out traditionally, so it is not surprising that the results obtained are relatively low. Cows are only ground or tethered at night, while in the afternoon they are released to look for food on the grass or in the sleeping area around the village. Only a small amount of effort has been made to raise livestock intensively by supplying and providing sufficient and regular food. The low level of livestock production is caused by the lack of knowledge of farmers in the proper way of raising livestock, also because of the lack of food both forage and the high price of concentrate. With the increase in the livestock population, it certainly requires more and sufficient forage throughout the year. However, the provision of forage has experienced serious obstacles. One of them is the existence of a dry season that causes a decrease in forage production. Therefore, the business of developing beef cattle will be more profitable if you can find alternative substitutes for conventional forage with the use of silos as feed fermentation sites. The use of agricultural products (such as rice straw) and other food crops as animal feed is expected to address the above problems. This is possible because cattle breeding is generally integrated with other farming businesses, especially food crops (rice fields) so that the results of agricultural follow-up will be available throughout the year. Therefore, there is a need for a kind of touch of feed technology with the use of agro-industry by products such as straw which are proven to be available at all times. The implementation of the application of rice straw ammoniation technology in the field with the direct administration of ammonia which has been removed and chicken manure is given. Participation and motivation of farmer groups in participating in a series of service activities is very high. Because all this time there has never been any guidance related to the technical and management aspects in the maintenance of beef cattle. Farmers already know how to manage fattening beef cattle such as giving concentrates such as coconut cake, soybean meal, fish meal, tofu pulp and bran and giving premix minerals.

Keywords: straw ammonia, concentrate, local feed, elephant grass

\section{PENDAHULUAN}

Pada dasarnya jerami padi diberikan pada ternak ruminansia apabila ketersediaan hijauan yang berkualitas lebih baik tidak mencukupi. Seperti kita ketahui, jerami padi mengandung dinding sel (cell wall constituent) yang tinggi yang diperkokoh dengan tingginya lignindan silika, sehinggasumberenersi yang tersimpan dalam bentuk selulosa dan hemiselulosa sulit dimanfaatkan oleh mikroorganisme rumen. Tingginya kadar lignin akan menghambat penetrasi bakteri rumen kedalam sel-sel tanaman (Harkin, 1973). Selain itu, jerami padi juga mengandung protein kasar dan mineral yang rendah, menyebabkan bahan ini tidak mampu menunjang produksi ternak, bahkan untuk kebutuhan hidup pokok sekalipun. Terbatasnya manfaat jerami padi sebagai pakan ternak disebabkan umurnya yang tua sehingga telah mengalami lignifikasi taraf lanjut yang menyebabkan sebagian besar karboidrat telah membentuk ikatan kokh dengan lignin membentuk ligno-selulosa dan ligno-hemiselulosa yang sulit dicerna. Menurut Minson (1967), kadar protein minimum untuk konsumsi normal dari suatu hijauan untuk ternak ruminansia adalah 7\%. Hasil penelitian Devendra (1975) memperlihatkan bahwa kompisisi kimia dan fraksi serat jerami dari berbagai varietas padi di Asia adalah sebagai berikut: protein kasar 3,3 - 4,5 \%, serat kasar 26-33,6\%, NDF 53,6-71,4\%, ADF 41,3-61,3\%, selulosa 24,3-34,3\%, lignin 5,5-12\% dan silika 
14,8-22,7\%. Usaha peningkatan kualitas jerami padi melalui kombinasi perlakuan fisik (pencicangan/pemotongan) dan kimiawi telah menunjukkan hasil yang mengembirakan. Dengan perlakuan ini, jerami padi dapat digunakan sebagai ransum basal ternak ruminansia dan mampu menunjang produktivitas ternak yang cukup tinggi. Salah satu perlakuan kimiawi yang paling populer dan efektif adalah amoniasi. Hasil penelitian Warly (1994) menunjukkan bahwa perlakuan amoniasi menunjukkan bahwa perlakuan amoniasi meningkatkan daya cerna jerami padi baik secara in vivo, invitro maupun in sacco.

Rumput gajah (Pennisetum purpureum) merupakan tanaman pakan yang berproduksi dan berkualitas tinggi dan juga mampu tumbuh dan berproduksi baik pada lahan marginal seperti lahan masam dan salin (Sumarsono, dkk. 2007). Pada kondisi ideal produksi rumput gajah cv. Taiwan dapat mencapai 270-300 ton bahan segar (BS)/ha/tahun (Suyitman dkk, 2003). Penggunaan pupuk urea pada penelitian ini berdasarkan Fedrial (2005) yakni $200 \mathrm{~kg} / \mathrm{ha}$. Tetapi penggunaan pupuk buatan secara terus menerus dapat menyebabkan turunnya produktivitas tanah. Sehingga diperlukan sumber $\mathrm{N}$ yang dapat memenuhi kebutuhan pertumbuhan tanaman tanpa memberikan dampak yang negatif. Pertanaman campuran antara rumput dan legum serta pemanfaatan pupuk hayati seperti CMA merupakan salah satu cara yang dapat digunakan.

Untuk menggerakkan kembali usaha peternakan sapi potong di Nagari Lambung Bukik khususnya Kelompok Tani Ternak Sungkai Permai sebagai penggerak usaha peternakan diperlukan semangat yang tinggi serta usaha yang semaksimal mungkin. Dalam hal ini Perguruan Tinggi (PT) sebagai nara sumber yang dapat mengaplikasikan ilmu pengetahuan (IPTEKS) yang dapat terjun langsung ke masyarakat untuk mengatasi problem yang ada dan dapat meningkatkan income serta meningkatkan kesejahteraan masyarakat. Penurunana perkembangan populasi sapi potong melalui beebrapai hasil penelitian terbukti dapat dipercepat melalui pemanfaatan pakan hasil agro industry by product seperti jerami dan pembuatan silo untuk fermentasi pakan serta penyusunan ransum yang tepat. Dosen Fakultas Peternakan yang handal dalam hal pemecahan masalah nutrisi pada ternak ruminansia/sapi potong dan dosen kimia dan farmasi yang akan memperhitungkan kandungan amoniasi dan pemberian $\mathrm{NH} 3$ yang sesuai dan tidak mengandung racun. Dengan pengalaman diatas diharapkan dapat mensupport peternak sehingga kembali tergerak hatinya untuk menghidupkan kembali usaha peternakan sapi potong yang sudah ada dengan adanya kegiatan IbDM kepada masyarakat.

Pada Pengbdian ini yang akan menjadi mitra adalah kelompok Tani/ternak "Sungkai Permai" yang terletak di Kampung Lambung Bukik, Kecamatan Pauh. Kelompok tani ini sudah berdiri sejak tahun 1997 dengan keanggotaan sekarang sebanyak 20 orang. Susunan Aktifitas dari kelompok mitra Sungkai Permai ini selain beternak juga mengadakan berbagai macam kegiatan seperti arisan, pembentukan pupuk organik untuk menanam rumput gajah. Tetapi mitra belum tersentuh dengan teknologi pemanfaatan amoniasi jerami dan bioteknologi CMA untuk pembuatan pellet indigofera berbasis kosentrat hijauan. Jenis sapi yang dipelihara pada umumnya adalah sapi Peranakan Onggole dan lokal. Secara umum, baik usaha pertanian maupun peternakan masih dilaksanakan secara semi tradisional, sehingga tidak mengherankan apabila hasil yang diperoleh pun relatif rendah. Ternak sapi hanya dikandangkan atau ditambatkan pada malam hari, sedangkan siang harinya dilepas untuk mencari makanan dipadang rumput atau dilahan tidur sekitar desa. Belum ada upaya untuk memelihara ternak 
secara intensif dengan mengandangkan dan memberikan makanan secara cukup dan teratur. Rendahnya produksi ternak selain disebabkan oleh kurangnya pengetahuan peternak dalam cara pemeliharaan ternak yang benar, juga karena kurangnya pakan baik hijauan maupun mahalnya harga konsentrat.

Meningkatnya populasi ternak tentu membutuhkan hijauan yang lebih banyak dan mencukupi sepanjang tahun. Namun, penyediaan hijauan tersebut mengalami hambatan yang cukup serius. Bukan saja karena semakin berkurangnya lahan yang dapat digunakan untuk penanaman rumput akibat terus meluasnya areal pemukiman dan tanaman pangan terutama di daerah padat penduduk, tetapi juga karena adanya musim kemarau yangmenyebabkan menurunnya produksi hijauan. Oleh karena itu usaha pengembangan ternak sapi potong dimasa mendatang akan lebih menguntungkan apabila dapat mencari alternatif pengganti hijauan konvensional dengan penggunaan silo sebagai tempat fermentasi pakan. Pemanfaatan hasil ikutan pertanian (seperti jerami padi) dan tanaman pangan lainnya sebagai pakan ternak diharapkan dapat menjawab permasalahan di atas. Hal ini dimungkinkan karena pemeliharaan ternak sapi di Bukik Lambung pada umumnya terintegrasi dengan usaha tani lainnya khususnya tanaman pangan (sawah) sehingga hasil ikutan pertanian akan tersedia sepanjang tahun. Keberadaan peternakan sapi potong yang cukup besar di sini telah membuat masyarakat di daerah lain ikut pula memelihara ternak sapi potong dengan pakan yang ada di sekitarnya. Kelompok tani "Sungkai Permai" belum tersentuhnya teknologi pakan dengan pemanfaatan agroindustri by product seperti jerami yang terbukti available setiap saat. Seperti telah diuraikan diatas, permasalahan pokok dalam pengembangan sapi potong di Lambung Bukik adalah rendahnya kuatitas dan kualitas pakan hijauan yang tersedia. Oleh karena itu pemanfaatan limbah pertanian khususnya jerami padi dipandang akan sangat menguntungkan karena jumlahnya tersedia sepanjang tahun. Setelah termanfaatkan dirasakan sangat perlu tempat penyimpanan hasil amoniasi jerami yaitu berupa silo yang dapat dimanfaatkan sebagai pakan ternak.

Peternak juga belum mengenal aplikasi sentuhan bioteknologi berupa cendawan mikoriza arbuskul (CMA) gomus manihottis yang dapat membantu penyerapan unsur hara. Disamping itu peternak mitra belum mengetahui pakan berbasis kosentrat hijauan berupa pellet Indigofera. Ketidatahuan bagaimana menyusun ransum yang baik juga menjadi kendala dalam meningkatkan performan ternak. Peternak mitra hanya bisa mencampur semua bahan pakan tanpa menyusun ransum yang seimbang dan mengahsilkan bobot badan yang baik. Akibatnya, terjadi penuruan bobot badan dan rentan terhadap penyakit.

\section{Metode Consuling}

\section{METODE}

Metode yang ditawarkan untuk mendukung realisasi program IbM yang akan dilaksanakan pada peternak mitra adalah metoda consuling dimana sebelumnya melaui pendekatan, kemudian diberikan penyuluhan, pelatihan danpembinaan serta terakhir adanya evaluasi dan monitoring berkelanjutan dari pihak Perguruan tinggi (PT). Hail dari monitoring nanti diharapkan akan meningkatkan keinginan dan semangat serta motivasi yang tinggi untuk meningkatkan taraf hidup dan kesejahteraan hidup. Hal ini dapat dicapai dengan pemanfaatan agroindustri by product seperti jerami amoniasi yang ditambahkan kotoran ayam serta mengetahui bagaimana penyusunan ransum yang tepat bagi pakan sapi potong dan paham cara memfermentasi di silo. Serta bagaimana 
penanaman rumput Gajah yang baik dan legume Indigofera sebagai pakan ternak.

\section{Rencana Kegiatan}

Langkah-langkah yang akan dilakukan untuk mengatasi persoalan yang dihadapi mitra adalah berpedoman kepada metode yang telah ditetapkan diatas, yaitu :

\section{a. Penyuluhan}

Cara yang paling efektif adalah dengan metoda penyuluhan. Dalam penyuluhan nanti diharapkan mampu menciptakan inovasi baru yang dapat diterapkan serta disosialisasikan di masyarakat. Materi-materi yang berkaitan akan diberikan sebelum penyuluhan dilakukan. Hal ini akan berguna bagi peternak untuk mengembangkan kewirausahaan dan peningkatan ekonomi masyarakat.

\section{b. Pelatihan}

Pelatihan yang akan diberikan meliputi pelatihan teknologi pengolahan pakan limbah, penyusunan/formulasi ransum, pelatihan teknologi amoniasi jerami ditambah kotoran ayam, pelatihan pembautan silo dan fungsinya serta pelatihan kewirausahaan dan pelatihan motivasi. Sebelum pelatihan, dipersiapkan materi-materi tentang kegiatan pelatihan yang akan diberikanDitinjau dari aspek pengolahan pakan, kepada peternak diberikan pelatihan "teknologi pengolahan pakan" agar bahan limbah cukup banyak tersedia di desa dapat diolah menjadi bahan makanan ternak ruminansia Selain itu, kepada peternak juga perlu diberi pengetahuan tentang penyusunan ransum menggunakan bahan limbah tersebut sehingga diperoleh ransum yang berkualitas dan berharga murah.

Pada pelatihan amoniasi, dipersiapkan sebuah silo sederhana kapasitas $100 \mathrm{~kg}$ jerami padi dan dipraktekkan bagaimana cara menggunakan silo tersebut. Penggunaan silo ini diharapkan dapat mempercepat fermentasi amoniasi jerami padi yang ditambah kotoran ayam dan menghidupkan kembli perekonomian masyararakat serta akan diberikan pelatihan bagaimana penanaman rumput Gajah dan Legume Indigofera yang baik serta dapat meningkat produksinya. Dalam pelatihan kewirausahaan dan motivasi, kepada peternak juga diberikan materi tentang penyusunan rencana bisnis sederhana sehingga pada akhir kegiatan peternak diharapkan mampu membuat rencana bisnis atau pembukuan sederhana untuk usaha mereka. Pada pelatihan motivasi, kepada peternak juga diberikan simulasi-simulasi praktis berwirausaha dengan tujuan akhir untuk meningkatkan motivasi peternak agar dapt meningkatkan taraf hidup.

\section{Bimbingan dan Pembinaan}

Setelah mendapatkan penyuluhan dan pelatihan, peternak akan dibimbing \pm 2 bulan dan dibina agar usaha peternakan sapi potong mereka yang menerapkan teknologi amoniasi, penanaman rumpt Gajah dan legume Indigofera dan fermentasi dengan silo dapat berjalan dengan baik sesuai dengan yang direncanakan.

\section{a. Monitoring}

Monitoring akan dilakukan secara berkala (1x2 minggu). Diskusi dan konsultasi akan dilakukan saat monitoring untuk mencari solusi dari berbagai kendala yang dihadapi baik dalam hal teknis peternakan maupun dalam hal kewirausahaan. Monitoring dilakukan oleh Tim pelaksana yang didampingi oleh Tim Universitas Andalas. 


\section{Evaluasi/ Pelaporan}

Pada awal dan akhir kegiatan akan dilakukan evaluasi dan akan disusun sebuah laporan akhir sebagai pertanggungjawaban terhadap kegiatan yang telah dilaksanakan.

\section{Partisipasi Mitra}

Untuk mensukseskan pelaksanaan program IbM ini, peternak mitra Kelompok Tani Peternak Sungkai Permai dan.diharapkan berpartisipasi aktif dalam beberapa hal, antara lain :

a. Keseriusan Mengikuti Rangkaian Kegiatan

Seluruh rangkaian kegiatan yang akan dilaksanakan mulai dari penyuluhan, pelatihan, bimbingan/pembinaan, monitoring dan evaluasi yang akan dilaksanakan oleh Tim Pelaksana diharapkan dapat terlaksana dengan baik. Hal ini berarti bahwa, setiap anggota kelompok peternak mitra diharapkan keseriusannya dalam mengikuti rangkaian kegiatan yang dilaksanakan sehingga tujuan akhir kegiatan untuk memberdayakan kelompok menjadi mandiri dapat dicapai dengan baik.

\section{b. Motivasi Harus Tinggi}

Keinginan yang tinggi serta motivasi yang kuat akan tercipta dengan adanaya pelatihan kewirausahan dan pelatihan motivasi yang diberikan diharapkan dapat membangkitkan usaha peternak sapi potong Simental.

\section{c. Kepastian Pelestarian/Keberlanjutan Kegiatan}

Setelah kegiatan selesai dilaksanakan, ketua kelompok peternak mitra diharapkan dapat membuat jadwal kegiatan pertemuan-pertemuan rutin (mingguan atau bulanan) yang berguna sebagai forum diskusi untuk mencari solusi dalam mengatasi berbagai persoalan yang dihadapi sekaligus memonitor kemajuan-kemajuan yang telah dicapai dalam pelaksanaan ipteks yang diterima dari tim pelaksanan. Hal ini berarti bahwa walaupun kegiatan oleh tim pelaksanan telah selesai, keberlanjutan kegiatan dapat dipertahankan.

\section{HASIL DAN PEMBAHASAN}

Telah dilakukan metode yang untuk mendukung realisasi program $\mathrm{IbM}$ yang dilaksanakan pada peternak mitra adalah metoda consuling dimana sebelumnya melaui pendekatan, kemudian diberikan penyuluhan, pelatihan dan pembinaan serta terakhir adanya evaluasi dan monitoring berkelanjutan dari pihak Perguruan tinggi (PT). Hasil dari monitoring diharapkan meningkatkan keinginan dan semangat serta motivasi yang tinggi untuk meningkatkan taraf hidup dan kesejahteraan hidup. Hal ini dapat dicapai dengan pemanfaatan agroindustri by product seperti jerami amoniasi yang ditambahkan kotoran ayam serta mengetahui bagaimana penyusunan ransum yang tepat bagi pakan sapi potong dan paham cara memfermentasi di silo.

Langkah-langkah yang telah dilakukan untuk mengatasi persoalan yang dihadapi mitra adalah berpedoman kepada metode yang telah ditetapkan diatas, yaitu :

\section{a. Penyuluhan}

Cara yang paling efektif adalah dengan metoda penyuluhan. Dalam penyuluhan petani telah mampu menciptakan inovasi baru yang dapat diterapkan serta 
disosialisasikan di masyarakat. Materi-materi yang berkaitan diberikan sebelum penyuluhan dilakukan. Hal ini berguna bagi peternak untuk mengembangkan kewirausahaan dan peningkatan ekonomi masyarakat.

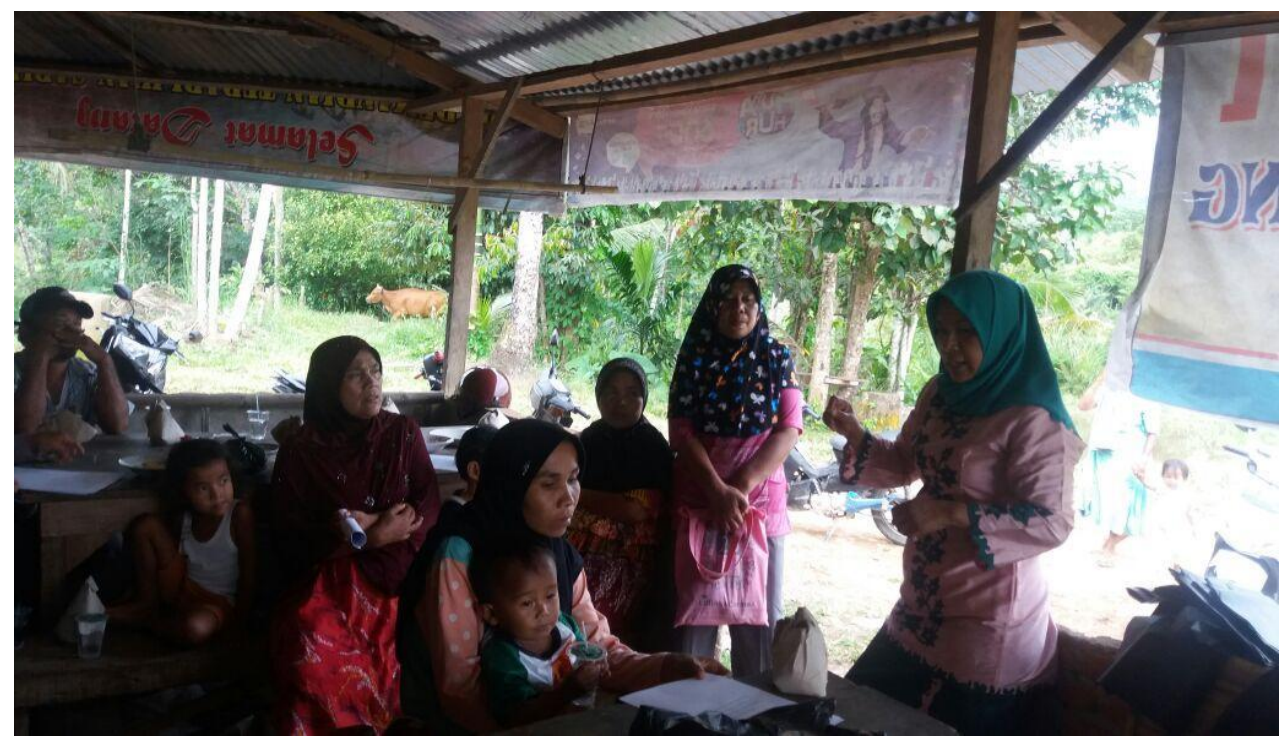

Gambar 1. Rapat dan Penyuluhan di Kelompok Tani.

\section{b. Pelatihan}

Pelatihan yang telah diberikan meliputi pelatihan teknologi pengolahan pakan limbah, penyusunan/formulasi ransum, pelatihan teknologi amoniasi jerami ditambah kotoran ayam, pelatihan pembautan silo dan fungsinya serta pelatihan kewirausahaan dan pelatihan motivasi. Sebelum pelatihan, dipersiapkan materi-materi tentang kegiatan pelatihan yang akan diberikan

Ditinjau dari aspek pengolahan pakan, kepada peternak telah diberikan pelatihan "teknologi pengolahan pakan" agar bahan limbah cukup banyak tersedia di desa dapat diolah menjadi bahan makanan ternak ruminansia Selain itu, kepada peternak juga diberi pengetahuan tentang penyusunan ransum menggunakan bahan limbah tersebut sehingga diperoleh ransum yang berkualitas dan berharga murah.

Pada pelatihan amoniasi, dipersiapkan sebuah silo sederhana kapasitas 31 ton jerami padi dan dipraktekkan bagaimana cara menggunakan silo tersebut. Penggunaan silo ini diharapkan dapat mempercepat fermentasi amoniasi jerami padi yang ditambah kotoran ayam dan menghidupkan kembli perekonomian masyararakat di Nagari Tiku, dapat dilihat pada gambar 2. dibawah ini. Sedangkan cara amoniasi sebagai berikut :

\section{Amoniasi Jerami Ditambah Kotoran Ayam}

a. Jerami padi dipotong-potong sepanjang $3-5 \mathrm{~cm}$ kemudian dimasukan ke dalamkantong-kantong plastk (polybag) rangkap 2 yang berkapasitas $5 \mathrm{~kg}$

b. Larutkan urea (4\%) diperoleh dengan cara melarutkan $40 \mathrm{~g}$ urea dalam 1 liter air. Larutan tersebut kemudian disiramkan secara merata ke dalam setiap kantong dengan menggunakan alat penyiram bunga.

c. Jerami padi dalam kantong dipadatkan kemudian segera diikat dengan karet. Kantong- kantong tersebut selanjutnya disimpan di dalam silo selama waktu yang 
telah ditentukan yaitu 5, 10, 15 dan 20 hari sumber enzim urease adalah kotoran ayam (poultry manure).

d. Ditambah kotoran ayam yang fungsinya juga mengurangi pencernaan lingkungan, penambahan bahan ini pada dosis $4 \%, 8 \%$ dan $12 \%$ ternyata efektif dalam menurunkan waktu amoniasi jerami padidari 21 hari menjadi 3 hari.

e. Sebelum dievaluasi nilai gizinya, jerami padi amoniasi dikering-anginkan selama 2 hari.

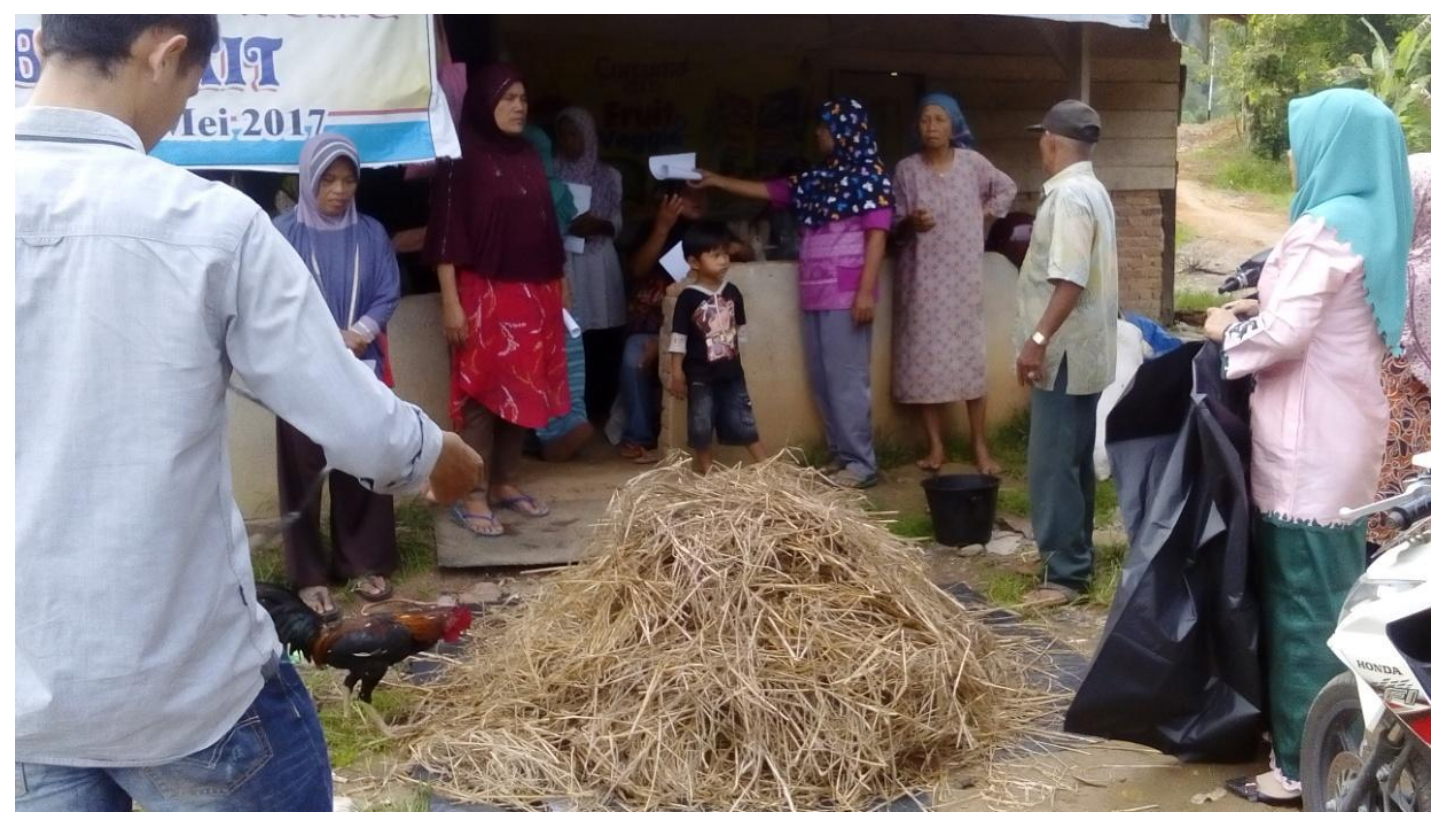

Gambar 2. Jerami yang di Amoniasi

Pelatihan kewirausahaan dan motivasi, kepada peternak juga diberikan materi tentang penyusunan rencana bisnis sederhana sehingga pada akhir kegiatan peternak diharapkan mampu membuat rencana bisnis atau pembukuan sederhana untuk usaha mereka. Pada pelatihan motivasi, kepada peternak juga diberikan simulasi-simulasi praktis berwirausaha dengan tujuan akhir untuk meningkatkan motivasi peternak agar dapt meningkatkan taraf hidup. Dapat kita lihat pada gambar 4 dibawah ini cara menyusun ransum sederhanan. 


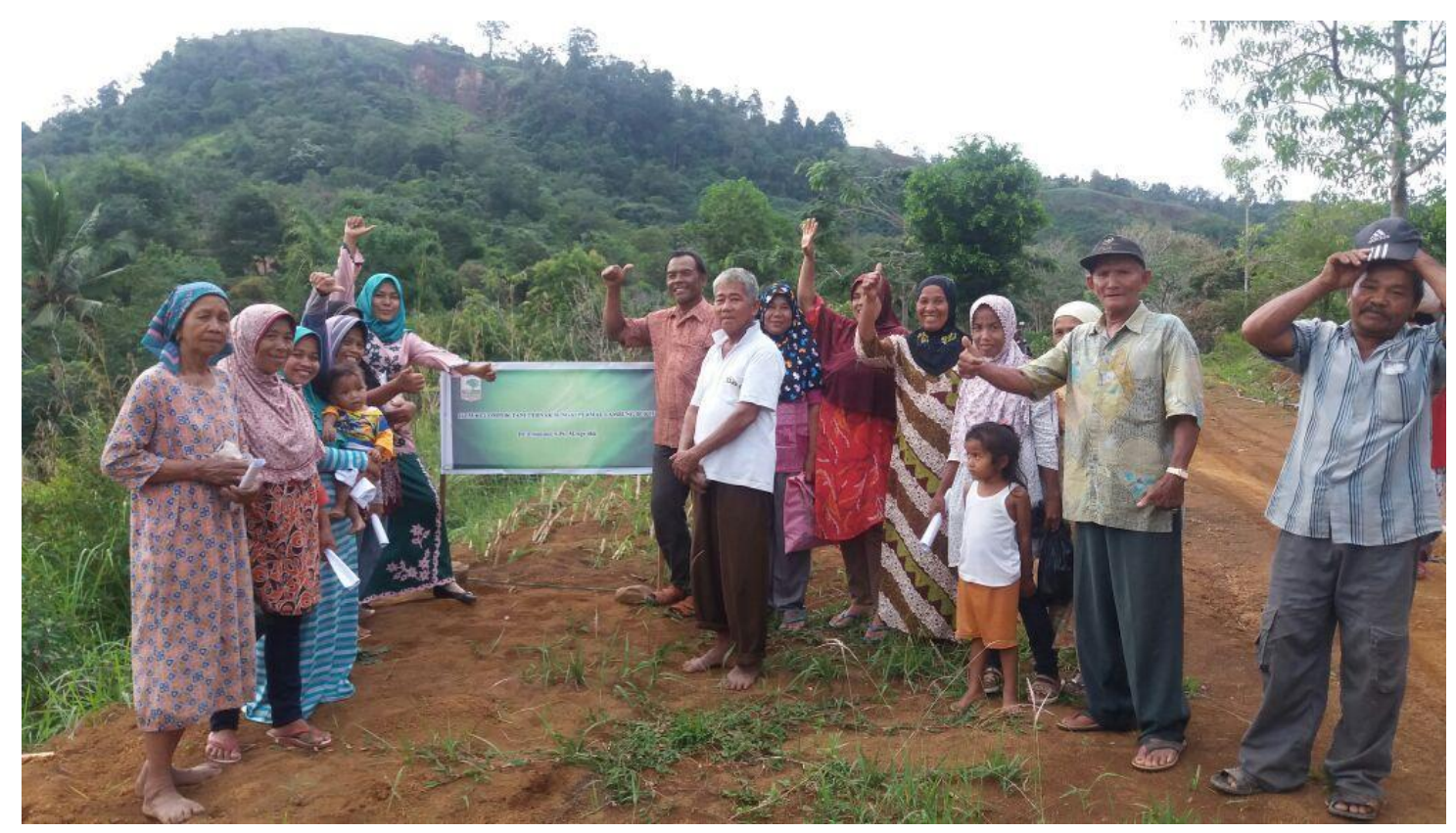

Gambar 3. Penanaman Rumput Gajah Unggul

\section{Penyusunan Ransum Untuk Sapi Potong/ Pedaging}

Menyusun ransum untuk seekor sapi jantan yang mempunyai berat badan $150 \mathrm{~kg}$ dengan PBB yang diharapkan $0.7 \mathrm{~kg} / \mathrm{hari}$. Bahan pakan yang tersedia adalah hijauan terdiri dari rumput gajah dan daun lamtoro $(60: 40)$, sedangkan konsentrat disusun dari onggok dan bungkil kelapa. Komposisi zat-zat makanan bahan dan kebutuhan sapi tersebut (\%) adalah :

\begin{tabular}{|l|r|r|r|r|r|}
\hline \multicolumn{1}{|c|}{ Bahan } & BK \% & PK (\%) & TDN (\%) & Ca (\%) & P (\%) \\
\hline Rumput gajah Daun & 22.2 & 8.69 & 52.4 & 0.475 & 0.347 \\
lamtoro Onggok & 24.8 & 24.2 & 74.4 & 1.68 & 0.21 \\
Bungkil Kelapa & 79.8 & 1.9 & 78.3 & - & - \\
Kebutuhan : & 88.6 & 21.3 & 78.7 & 0.185 & 0.616 \\
& $3.9 \mathrm{~kg} / \mathrm{h}$ & 12.6 & 70 & 0.46 & 0.36 \\
\hline
\end{tabular}

Penyusunan ransum diadasarkan pada kebutuhan enersi (TDN)

1. Kebutuhan $\mathrm{BK}=3.9 \mathrm{~kg} / \mathrm{h} ; \mathrm{TDN}=70 / 100 \times 3.9 \mathrm{~kg}=2.73 \mathrm{~kg} / \mathrm{h}$

BK ransum berasal dari hijauan berdasarkan tabel kebutuhan adalah $50 \%$

$=50 / 100 \times 3.9=1.95 \mathrm{~kg}$, terdiri dari :

- BK dari rumput gajah $=60 / 100 \times 1.95 \mathrm{~kg}=1.17 \mathrm{~kg}$

- BK dari daun lamtoro $=40 / 100 \times 1.95 \mathrm{~kg}=0.78 \mathrm{~kg}$

2. BK berasal dari konsentrat $=3.9-1.95=1.95 \mathrm{~kg}$

3. TDN dari rumput gajah $=52.4 / 100 \times 1.17=0.613 \mathrm{~kg}$

4. TDN dari daun lamtoro $=74.4 / 100 \times 0.78=0.580 \mathrm{~kg}$

5. TDN yang harus dipenuhi dari konsentrat (onggok dan bungkil kelapa) adalah :

$=2.73-0.613-0.580=1.537 \mathrm{~kg}$ atau $1.537 / 1.95 \times 100 \%=78.8 \%$ 
Onggok dan bungkil kelapa yang harus dipenuhi adalah :

Onggok bungkil kelapa

(78.3) (78.7) (78.8)

(0.1) (0.5) Jumlah $=0.6$

Onggok $=(0.1 / 0.6) \times 100 \%=16.67 \%$ atau $0.1667 \times 1.95=0.325 \mathrm{~kg}$ BK ransum Bungkil kelapa $=(0.5 / 0.6) \times 100 \%=83.33 \%$ atau $0.8333 \times 1.95 \mathrm{~kg}=1.625 \mathrm{~kg} \mathrm{BK}$ ransum

Sedangkan, untuk mengaduk ransum dapat kita lakukan pada tempat pengaduk ransum sehingga merata dalam hal pemberian pakan kepada ternak nantinya.

\section{b. Bimbingan dan Pembinaan}

Setelah mendapatkan penyuluhan dan pelatihan, peternak telah dibimbing \pm 2 bulan dan dibina agar usaha peternakan sapi potong mereka yang menerapkan teknologi amoniasi dan fermentasi dengan silo dapat berjalan dengan baik sesuai dengan yang direncanakan.

\section{c. Monitoring}

Monitoring telah dilakukan secara berkala ( 1 x 2 minggu). Diskusi dan konsultasi telah dilakukan saat monitoring untuk mencari solusi dari berbagai kendala yang dihadapi baik dalam hal teknis peternakan maupun dalam hal kewirausahaan. Monitoring telah dilakukan oleh Tim pelaksana yang didampingi oleh Tim Universitas Andalas.

\section{d. Evaluasi/pelaporan}

Pada awal dan akhir kegiatan akan dilakukan evaluasi dan akan disusun sebuah laporan akhir sebagai pertanggungjawaban terhadap kegiatan yang telah dilaksanakan.

\section{Partisipasi Mitra}

Untuk mensukseskan pelaksanaan program IbM ini, peternak mitra Kelompok Tani Cemara Tiga Jorong gasan Kaciak diharapkan berpartisipasi aktif dalam beberapa hal, antara lain :

\section{c. Keseriusan Mengikuti Rangkaian Kegiatan}

Seluruh rangkaian kegiatan yang telah dilaksanakan mulai dari penyuluhan, pelatihan, bimbingan/pembinaan, monitoring dan evaluasi telah dilaksanakan oleh Tim Pelaksana diharapkan telah terlaksana dengan baik. Hal ini berarti bahwa, setiap anggota kelompok peternak mitra serius dalam mengikuti rangkaian kegiatan yang dilaksanakan sehingga tujuan akhir kegiatan untuk memberdayakan kelompok menjadi mandiri dapat dicapai dengan baik.

\section{d. Motivasi Harus Tinggi}

Keinginan yang tinggi serta motivasi yang kuat akan tercipta dengan adanaya pelatihan kewirausahan dan pelatihan motivasi yang diberikan diharapkan dapat membangkitkan usaha peternak sapi potong di Tiku Selatan, kabupaten Agam.

\section{e. Kepastian Pelestarian/Keberlanjutan Kegiatan}

Setelah kegiatan selesai dilaksanakan, ketua kelompok peternak mitra telah 
membuat jadwal kegiatan pertemuan-pertemuan rutin (mingguan atau bulanan) yang berguna sebagai forum diskusi untuk mencari solusi dalam mengatasi berbagai persoalan yang dihadapi sekaligus memonitor kemajuan-kemajuan yang telah dicapai dalam pelaksanaan ipteks yang diterima dari tim pelaksanan. Hal ini berarti bahwa walaupun kegiatan oleh tim pelaksanan telah selesai, keberlanjutan kegiatan dapat dipertahankan

\section{Target Luaran}

1. Mengurangi ketergantungan peternak akan rumput unggul atau rumput yang biasa diberikan sehari-hari kepada sapi potong.

2. Memberikan masukan teknologi tepat guna bagi peternak dalam memanfaatkan jerami padi sebagai sumber hijauan pengganti rumput dalam ransum ternak sapi potong melalui perlakuan amoniasi-urea.

3. Mengurangi ketergantungan peternak terhadap konsentrat komersial dengan cara membuat sendiri konsentrat dari bahan yang murah dan mudah didapat.

4. Publikasi pada jurnal skala nasional sehingga diharapkan ilmu tersebut mampu di adaptasi oleh peternak atau ilmuwan lainnya.

Teknologi pada bahan pakan limbah yang dilakukan peternak akan dianalisis kandungan gizinya dengan "proximat analisis". Standar hasil yang diharapkan adalah peningkatan protein dan penurunan kadar serat kasar bahan limbah yang telah diolah (protein $\pm 18 \%$ dan serat kasar $\pm 6 \%$ )

Disamping itu, masalah lain yang juga perlu mendapat perhatian adalah meningkatkan motivasi peternak untuk kembali berusaha sehingga kegairahan untuk beternak meningkat kembali. Dengan pengalaman kewirausahaan juga telah dimiliki oleh tim pelaksana kegiatan diharapkan kegiatan "Ipteks Bagi Masyarakat" yang akan dilaksanakan ini diyakini akan dapat berjalan dengan baik dan dapat menggerakkan/menggairahkan kembali usaha peternak sapi potong dan roda ekonomi masyarakat di Nagari Tiku Kabupaten Agam.

\section{Kesimpulan}

\section{KESIMPULAN DAN SARAN}

Berdasarkan hasil kegiatan yang telah dilaksanakan dapat disimpulkan: 1. Adanya partisipasi dan motivasi yang tinggi dari kelompok peternak, masyarakat, 2. PPL dan instansi terkait dalam mengikuti kegiatan, 3. Petani peternak telah tahu pemberian pakan konsentrat untuk meningkatkan bobot badan sapi, 4. Petani peternak mampu membuat amoniasi jerami yang dapat digunakan sebagai pengganti hijauan disaat panen jerami dan 5. Peternak mengetahui cara menanam hijauan unggul seperti rumput gajah.

\section{Saran}

Perlu adanya pembinaan berkelanjutan karena masih baru berdirinya maka perlu pendampingan agar motivasi dan semangat terus meningkat. Selanjutnya Pemda dalam hal ini dinas pertanian melalui sub dinas peternakan menjadikan Tiku Selatan sebagai kawasan sentra sapi potong. Perlu dilakukan kegiatan yang berulang terutama permintaan dana yang langsung memakai ternak sebagai faktor utama dalam hal penggemukan sapi potong. 


\section{DAFTAR PUSTAKA}

Ambar, A.R and A. Djayanegara. 1982. The Effects of Urea Treatment on Disapperearance of Dry Matter and Fiber of Rice Straw from Nylon Bags. In: The Utilization of Fibrous Agricultural Residues as Animal Feeds. Ed. By. P.T. Doyle. School and Agriculture and forestry University of Melbourne.

Church, D.C. and A. Santos, 1981. Effect of graded levels of soybean meal and nonprotein nitrogen-molasses supplement on consumption and digestibility of wheat straw. J. Anim. Sci. (70) : 1534-1542.

Chuzaemi, S. dan M. Soejono, 1987. Pengaruh urea amoniasi terhadap komposisi kimia dan nilai gizi jerami padi untuk sapi PO. Proceeding Limbah Pertanian Sebagai Pakan Dan Manfaatnya. Fakultas Peternakan Universitas Gajah Mada.

Devendra, C., 1975. The Utilization of rice straw by sheep. 1. optimal level in the diet. Malays. Agric. J. 51: 280-290.

Doyle, P.T., H. Dove, M. Freer, F.J. Hart, R.M. Dixon and A.R. Egan, 1988. Effects of concentrate supplement on the intake and digestion of low quality forage by lambs. J. Agric. Sci., Camb. 111: 503-511.

Fedrial, J. 2005. Pengaruh peningkatan takaran pemupukan N, P, dan K terhadap pertumbuhan dan produksi rumput benggala (Panicum maximum) pada tanah PMK pemotongan pertama. Skripsi. Fakultas Peternakan Universitas Andalas, Padang.

Harkin, J. M. 1973. Lignin. In: Chemistry and Biochemistry of Herbage. Ed. By : G.W.

Ibrahim, M. N. M. 1986. Rice Bran as a Supplement for Straw Based Rations. in: Ruminant Feeding Systems Utilizing Fibrous Agricultural Residues. Ed. R.M. Dixon. School of Agriculture and Forestry, University of Melbourne, Austarlia: 139-145.

Liu, J.X., M. Okubo and Y. Asahida, 1988. Effects of soybean meal supplementation on fiber digestion in the rumen and voluntary intake of rice straw by sheep. Jpn. Zootech. Sci., 59(12): 1034-1039.

Saadullah, M., Haque, M. And Dolberg, F., 1981. Effectiveness of amonification through urea in improving the feeding value of rice straw in ruminants. Trop. Anim. Prod. 6: 30-36.

Silva, A.T., J.T.D Greenhalgh and E.R. Orskov, 1989. Influence of ammonia treatment and supplementation on the intake, digestibility and weight gain of sheep and cattle on barley straw diets. Anim. Prod., (48) : 99-108. 
Sumarsono, S. Anwar, S. Budianto dan D.W. Widjajanto. 2007. Penampilan morfologi dan produksi bahan kering hijauan rumput gajah dan kolonjono di lahan pantai yang di pupuk dengan pupuk organik dan dua level pupuk urea. J. Pengembangan Peternakan Tropis. 32(1) : 58 - 63

Suyitman, S. Jalaluddin, Abudinar, N. Muis, Ifradi, N. Jamaran, M. Peto, dan Tanamasni. 2003. Agrostologi. Diktat. Fakultas Peternakan Universitas Andalas. Padang.

Warly, L., 1994. Study on Improving Nutritive Value of Rice Straw and PhysicoChemical Aspects of Its Digestion in Sheep. Ph.D Thesis. The United Graduated School of Agriculture Sciences, Tottori University, Japan.

Wibawa, P. Parwata, A. Wirawan. Sumardani, dan Suberata. 2014. Respon rumput gajah (Pennisetum purpureum schumach) terhadap aplikasi pupuk urea, kotoran ayam, dan kotoran sapi sebagai sumber nitrogen. Majalah Ilmiah Peternakan. Vol. 17 No:2 